|Rafiqah

\title{
ANALISIS SHARI'AH COMPLIANCE PADA TRADING FOREX ONLINE
}

\author{
Rafiqah \\ Universitas Iskandar Muda (UNIDA) Banda Aceh \\ rafiqah_ahmad@yahoo.com
}

\begin{abstract}
Abstrak
Penelitian ini bertujuan untuk mengetahui bagaimana operasional trading forex online baik yang Islami maupun yang konvensional dan kesesuaiannya dengan prisip-prinsip bay' Sharf dalam Islam, selain itu artikel ini juga menganalisa unsur-unsur syariah compliance yang ada pada trading tersebut. Ide dan pemikiran tentang rancangan konsep trading forex online yang Islami juga menjadi fokus dalam penelitian ini. Pendekatan yang dilakukan dalam penelitian ini adalah pendekatan deskriptif atas data kualitatif di mana akan dijelaskan fakta yang terjadi di dalam operasional trading forex online untuk kemudian dilihat kesesuaiannya dengan prinsip-prinsip Islam secara komprehensif. Temuan penelitian ini adalah bahwa meskipun sekilas Islamic forex trading berbeda dengan conventional forex trading, namun masih terkesan bias di mana secara teknis hampir tidak terdapat perbedaan yang signifikan antara kedua type transaksi tersebut. Artinya meskipun para broker akun forex Islami menawarkan transaksi tanpa elemen Rollever Interest, ${ }^{1}$ namun sebagian besar dari mereka masih mengenakan fee lainnya atas trader yang melakukan open positon lebih dari semalam, atau mengenakan kadar spread yang lebih tinggi menggantikan rollever interes.
\end{abstract}

Kata Kunci: trading; forex online; shariah compliance

${ }^{1}$ Rollover interest adalah charge yang dikenakan oleh broker atas trader yang posisinya terbuka lebih dari 24 jam. Charge ini dikarenakan dana yang dipergunakan dalam trading sifatnya adalah pinjaman dari broker kepada trader melalui konsep leverage. 


\section{A. Pendahuluan}

Selama ini, negative thinking berkembang di masyarakat tentang trading online baik trading saham, forex (foreign exchange), komoditi maupun instrument keuangan lainnya. Trading online terutama forex dianggap sarat dengan unsur riba, spekulasi, gambling, yang diharamkan dalam Islam. Stereotype tersebut menyebabkan peluang usaha/bisnis online trading forex seringkali dipandang sebelah mata oleh masyarakat. Padahal bisnis forex adalah bisnis dengan liquidasi tertinggi nomor 1 (satu) di dunia.

Menurut BIS (Bank International for Settlement), rata-rata perputaran uang dalam transaksi trading foreign exchange dunia per-hari di luar bursa (over the counter) diperkirakan senilai 3,21 triliun dolar AS. Unsur spekulasi dalam trading forex online merupakan isu utama yang sejak lama menjadi sorotan tajam para ulama dan ekonom muslim, mengingat bisnis forex adalah bisnis yang beresiko tinggi yang dapat mengakibatkan kerugian finansial bahkan kebangkrutan dalam waktu relatif singkat. Di samping itu isu riba dalam transaksi forex juga masih menjadi perdebatan sengit di kalangan ekonom muslim.

Meskipun demikian, laju perkembangan bisnis ini sulit dibendung dan bahkan makin banyak diminati terutama oleh para investor/trader muslim. Dibutuhkan sebuah format baku tentang trading forex online yang sejalan dengan prinsip-prinsip syariah sehingga umat Islampun dapat ikut berperan serta dalam aktifitas bisnis tersebut.

Sulit dipungkiri bahwa dari berbagai survey, ditemukan hampir sekitar $80 \%$ dari trader mengalami kerugian finansial, dan hanya $20 \%$ saja dari mereka yang sukses dengan profit yang konsisten. Jesse Livermor sebagaiman dikutip oleh Ellen May, mengeluarkan statement yang terkesan ekstrim, yaitu: "The Stock Market is Never Obvious; it was to fool most of People, most of the time."

${ }^{2}$ Ellen May, Smart Trader not Gambler (Jakarta: PT. Gramedia Pustaka Utama, 2011), 8. 
Dominic Corelo sebagaimana dikutip oleh Marjan Muhammad dkk, juga memaparkan bahwa berdasarkan analisa empiric ternyata sekitar 95\% trader yang berbisnis di trading forex online mengalami kerugian total hanya dalam waktu singkat. ${ }^{3}$ Bahkan mayoritas broker membuat pernyataan risk disclosure/risk warning dalam laman mereka untuk mengingatkan trader agar berhati-hati dalam melakukan transaksi karena resiko dalam bisnis ini sangat tinggi. Contoh dari pernyataan tersebut adalah: (1) "Forex trading involves substantial risk of loss and is not suitable for all investors." ${ }^{\text {"4 }}$ (2) "Trading foreign exchange on margin carries a high level of risk, and may not be suitable for all investors. The high degree of leverage can work against you as well as for you.",

Menurut Ali Karbalaee, resiko utama dalam trading forex sebenarnya terdapat pada market risk selain resiko pada liquidity, credit dan control. Resiko pasar yang hampir sepenuhnya bergantung kepada market volatilities tersebut dapat mengakibatkan kerugian finansial bagi para trader. ${ }^{6}$ Penelitian ini juaga menemukan bahwa berdasarkan analisa menggunakan indicator Reversal dengan time friem empat jam, diketahui bahwa kerugian trader diakibatkan oleh the size of position dan bukan oleh initial deposit. ${ }^{7}$

\footnotetext{
${ }^{3}$ Marjan Muhammad, dkk, Operasi Perdagangan Mata Uang Asing oleh Individu Secara Lani (Individual Spot Forex) melalui Platfom Elektronik; Satu Sorotan dari Sudut Syariah, 46. Rujuk juga: Dominic Corelo, "Succsessful Spot Forex Trading Requires Mentality of Marathon Runner," 26 Februari 2011. http://succsesstipsforex.com.

4 Risk warning oleh broker FXSolution di http: www.fxsolution.com. Diunduh tanggal 27 September 2019.

${ }^{5}$ Risk warning oleh broker FXCM. http:www.forexmicrolot.com, diunduh pada tanggal 27 September 2019.

6 Ali Karbalaee, "Risk and Return in Retail Forex," Journal of Social Science Research Network, June 15, 2012, pp: 1-40. http://dx.doi.org, Diakeses pada tanggal 8 Oktober 2019.

${ }^{7}$ Initial deposit atau biasa disebut dengan initial margin, yaitu sejumlah dana yang harus disetorkan oleh investor pada saat pembukaan account di perusahaan pialang. Jumlah setorannya sesuai dengan kesepakatan awal yang dibuat antara investor dengan perusahaan pialang, yang biasanya dinyatakan dalam persentase dari nilai kontrak. Dalam perdagangan forex, initial margin ditetapkan sebesar $1 \%$ dari nilai kontrak. Nilai kontrak itu sendiri terbagi kepada dua kategori, kategori pertama adalah kontrak besar: USD 100.000, sedangkan kategori kedua adalah kontrak kecil: USD 10.000. Jadi, besarnya nilai margin di sini adalah sebesar USD 1000 (Rp.10.000.000,-) atau USD 100 (Rp.1.000.000,-), jika kurs rupiah ditetapkan Rp.10.000 per dollar AS. Lihat http://www.okeforex.com.
} 
Di samping itu isu riba dalam transaksi forex juga masih menjadi perdebatan sengit di kalangan pakar ekonomi Islam. Azwina Wati Binti Abdul Manaf, dan Ruzian Binti Markom, dalam research-nya yang berjudul Currency Trading in Modern Islamic Bank in Malaysia, menjelaskan bahwa forex trading merupakan salah satu isu hangat yang menjadi topik pembahasan para ulama dan pakar ekonomi Islam. Pada dasarnya forex trading memang diperlukan oleh mereka yang bepergian ke luar negeri, di mana mereka menukarkan mata uang negaranya dengan mata uang negara yang akan dikunjungi untuk kebutuhan transaksi di sana. Namun dalam perkembangannya, trading forex dijadikan alat spekulasi bagi para trader untuk memperoleh profit melalui volatilitas harga. Padahal Islam melarang barter mata uang emas dan perak dengan selisih harga, hal itu dikarenakan uang merupakan salah satu dari enam item komoditi yang hanya boleh ditukarkan dengan nilai yang sama, sebagaimana di sebutkan dalam Hadits. ${ }^{8}$ Meskipun mata uang yang beredar sekarang adalah mata uang kertas namun dari aspek hukum adalah sama dengan mata uang emas dan perak. Dengan demikian, trading forex tidak diperbolehkan karena terindikasi riba. ${ }^{9}$

Tidak bisa diperdagangkan untuk menghasilkan uang. Di sini uang hanya berfungsi sebagai modal dan alat tukar. Jadi menurut mereka, trading forex bertentangan dengan prisip-prinsip ajaran Islam karena mengeksploitasi fungsi uang menjadi sebuah komoditi perdagangan. ${ }^{10}$

\footnotetext{
${ }^{8}$ Berikut adalah terjemahan dari hadits yang disebutkan diatas: Dari Abu Bakrah ra. dia berkata: Rasulullah Saw telah melarang (pertukaran) perak dengan perak, emas dengan emas, kecuali sama jumlahnya. Nabi menyuruh kami agar membeli perak (dibayar) dengan emas menurut kehendak kami dan membeli emas (dibayar) dengan perak menurut kehendak kami. Seorang lakilaki bertanya: "Apakah harus ada serah terima? "Abu Bakrah berkata: "demikianlah yang aku dengar." (mutaffaqun 'alaih).

${ }^{9}$ Azwina Wati Binti Abdull Manaf, dan Ruzian Binti Markom, "Currency Trading in Modern Islamic Bank in Malaysia, ’Journal of IcoGBSE Langkawi, 2015, e-ISBN:9789671371800, 1-2. http://www.gbse.com.my, diunduh tanggal 02 September 2019.

${ }_{10}$ Syed Adam Alhabshi, "The Role Of Money In Islamic Banking And Finance." Current Law Journal (Syariah Reports),Vol.1, No.Liii (2010). http://ajbasweb.com, diunduh tanggal 28 September 2019.
} 
Meskipun masih terdapat pro dan kontra seputar isu-isu trading online, namun laju perkembangan bisnis ini sulit dibendung dan bahkan makin banyak diminati oleh para investor/trader. Untuk menyikapi hal ini, dan sekaligus menjawab kebutuhan masyarakat muslim akan sebuah format trading forex online yang sejalan dengan keyakinan agama yang mereka anut, beberapa perusahaan pialang atau broker menawarkan akun Islamic Forex OnlineTrading atau dikenal juga dengan akun Islami non Swap, yang diperuntukkan bagi nasabah muslim. Para broker tersebut mengklaim bahwa bisnis forex yang mereka kelola sudah sesuai dengan prisip-prinsip Islam. Broker-broker dimaksud antara lain ${ }^{11}$ : MFFX, Instaforex, Market.com, Etoro, didirikan pada tahun 2007 di Cyprus, AvaTrade, FXCM yang bermarkas di USA, dan XForex

Namun sejauh mana Islamic Forex Trading berbeda dengan Konvensional forex trading, nampaknya masih terkesan bias di mana secara teknis hampir tidak terdapat perbedaan yang signifikan antara kedua type transaksi tersebut. ${ }^{12}$

Team research ISRA (International Syariah Reasearch Academy for Islamic Finance), menyatakan bahwa meskipun para broker akun forex Islami menawarkan transaksi tanpa elemen Rollever Interest, ${ }^{13}$ namun sebagaian besar dari mereka masih mengenakan fee lainnya atas trader yang melakukan open positon lebih dari semalam, atau mengenakan kadar spread yang lebih tinggi menggantikan rollever interest. ${ }^{14}$

\footnotetext{
${ }^{11}$ www.Dailyforex.com, Islamic Forex Brokers Reviews, diunduh tanggal 7 September 2019.

12 Fakhry Rafik, Omar dan Eleri Jones, "Critical evaluation of the compliance of online Islamic FOREX trading with Islamic principles," International Journal of Islamic and Middle Eastern Finance and Management, Vol. 8 Iss: 1 (2015), pp.64-84.

${ }^{13}$ Rollover interest adalah charge yang dikenakan oleh broker atas trader yang posisinya terbuka lebih dari 24 jam. Charge ini dikarenakan dana yang dipergunakan dalam trading sifatnya adalah pinjaman dari broker kepada trader melalui konsep leverage.

${ }^{14}$ Marjan Muhammad, Lokmanulhakim Hussain, MD. Som Sujimon, dan Won Norhaziki Wan Abdul Halim, "Operasi Perdagangan Mata Uang Asing oleh Individu Secara Lani (Individual Spot Forex) melalui Platfom Elektronik; Satu Sorotan dari Sudut Syariah”, (Kuala Lumpur: 2011, ISRA (International Syariah Research Academy for Islamic Finance), 37-39. Lihat juga http://globextrade.com.
} 


\section{B. Literatur Review dan Diskusi}

Berdasarkan Literasi, Forex adalah singkatan dari foreighn currency exchange ${ }^{15}$ artinya pertukaran mata uang asing atau yang lebih dikenal dengan valas, sedangkan secara etimologi forex adalah suatu jenis transaksi perdagangan mata uang negara tertentu dengan mata uang negara lain. ${ }^{16}$

Transaksi Forex ini berlangsung terus menerus selama 24 jam sehari, di mana pergerakan pasar dimulai dari Selandia Baru dan Australia dengan open market jam 05.00-14.000, disusul oleh market Asia (Jepang, Singapura dan Honkong) yang dibuka pada pukul 07.00-16-00. Sementara itu pasar Eropa (Jerman dan Inggris) memulai transaksinya jam 13.00-22.00 dan Amerika Serikat sebagai negara yang paling terakhir memulai membuka marketnya, yaitu pada pukul 20.30-22.00.

Transaksi Forex memiliki tingkat likuiditas dan pergerakan harga yang sangat cepat sehingga mengalahkan transaksi-transaksi lainnya, sebagaimana hasil survey Bank International for Settlement (BIS) dimana nilai transaksi forex di seluruh dunia mencapai angka USD \$3,21 triliun perhari. Hal ini menjadikan forex sebagai primodana investasi dengan tingkat ROI (return on investasment) dan profit yang tinggi melebihi transaksi bisnis lainnya.

Jika dikaji lebih jauh, pada dasarnya pendapat yang memperbolehkan trading forex online berpijak pada prinsip bahwa segala bentuk akad-akad muamalah yang bersifat ijtihadiyah adalah diperbolehkan (al-ibahah) selama belum ada dalil yang mengharamkannya. Mereka berpatokan pada aksioma (al-qa'idah al-fiqhiyyah) yaitu:

$$
\text { الأصل في المعاملة الإباحة إلا أن يدل الدليل على تحريمها. } 17
$$

Artinya: "Hukum asal dalam muamalah adalah boleh dilaksanakan, kecuali ada dalil yang mengharamkannya."

${ }^{15}$ Oxford Dictionary of Finance an Banking, OXFORD University Press, Edisi ke-3, 2005, 165.

${ }^{16} \mathrm{https}: / /$ id.wikipedia.org, diunduh pada 15 Okteober 2019.

17 Muhammad Rawwas Qal'ah Jiy, al-Mu'amalat al-Maaliyah alMu'asirah fi Dhau'i al-Fiqh wa al-Syari'ah (Beirut: Dar al-Nafais, 1999), 11. Lihat juga, 'Ali Ahmad al-Nadwi, al-Qawa'id al-Fiqhiyyah (Beirut: Dar alQalam, 1998), 36. 
Majelis Ulama Indonesia (MUI) juga memperbolehkan transaksi forex dengan beberapa ketentuan. Dalam fatwanya No.28/DSN-MUI/III/2002 Tentang Jual Beli Mata Uang (alSharf) diputuskan bahwa transaksi jual beli mata uang pada prinsipnya adalah boleh dengan beberapa ketentuan salah satunya adalah tidak untuk tujuan spekulasi atau untung-untungan. Berikut bunyi dari fatwa tersebut: Bahwa transaksi transaksi jual beli mata uang pada prinsipnya boleh dengan ketentuan sebagai berikut:

a) Tidak untuk spekulasi (untung-untungan)

b) Adanya kebutuhan transaksi atau untuk berjaga-jaga (simpanan)

c) Apabila transaksi dilakukan terhadap mata uang sejenis maka nilainya harus sama dan secara tunai (at-taqabudh).

d) Apabila berlainan jenis maka harus dilakukan dengan nilai tukar (kurs) yang berlaku pada saat transaksi dilakukan dan secara tunai. Jenis-Jenis Transaksi Valuta Asing:

1) Transaksi Spot

Yaitu transaksi pembelian dan penjualan valuta asing (valas) untuk penyerahan pada saat itu (over the counter) atau penyelesaiannya paling lambat dalam jangka waktu dua hari. Hukumnya adalah boleh, karena dianggap tunai, sedangkan waktu dua hari dianggap sebagai proses penyelesaian yang tidak bisa dihindari (بِمَّا لاَبُدْ منه) dan merupakan transaksi internasional.

2) Transaksi Forward

Yaitu transaksi pembelian dan penjualan valas yang nilainya ditetapkan pada saat sekarang dan diberlakukan untuk waktu yang akan datang, antara 2 x 24 jam sampai dengan satu tahun. Hukumnya adalah haram, karena harga yang digunakan adalah harga yang diperjanjikan (muwa'adah) dan penyerahannya dilakukan di kemudian hari, padahal harga pada waktu penyerahan tersebut belum tentu sama dengan nilai yang disepakati, kecuali dilakukan dalam bentuk forward agreement untuk kebutuhan yang tidak dapat dihindari (lil hajah).

3) Transaksi Swap

Yaitu suatu kontrak pembelian atau penjualan valas dengan harga spot yang dikombinasikan dengan pembelian antara penjualan valas yang sama dengan harga forward. Hukumnya haram, karena mengandung unsur maisir (spekulasi). 


\section{4) Transaksi Option}

Yaitu kontrak untuk memperoleh hak dalam rangka membeli atau hak untuk menjual yang tidak harus dilakukan atas sejumlah unit valuta asing pada harga dan jangka waktu atau tanggal akhir tertentu. Hukumnya haram, karena mengandung unsur maisir (spekulasi)."

Sementara itu sebagian pakar ekonomi kontemporer, membedakan hukum trading forex berdasarkan jenis transaksinya. Sebagaimana kita ketahui bahwa transaksi derivative ${ }^{19}$ terbagi kepada beberapa jenis transaksi, ${ }^{20}$ yaitu: Forward, ${ }^{21}$ Futures, ${ }^{22}$ Option, ${ }^{23}$ dan Swap. ${ }^{24}$

\footnotetext{
${ }^{18} \mathrm{http}: / / w w w . d s n m u i . o r . i d$, diunduh pada tanggal 27 September 2019.

${ }^{19}$ Derivatif adalah sebuah kontrak bilateral atau perjanjian penukaran pembayaran yang nilainya diturunkan atau berasal dari produk yang menjadi "acuan pokok" atau juga disebut "produk turunan" (underlying product); daripada memperdagangkan atau menukarkan secara fisik suatu aset, pelaku pasar membuat suatu perjanjian untuk saling mempertukarkan uang, aset atau suatu nilai disuatu masa yang akan datang dengan mengacu pada aset yang menjadi acuan pokok. Derivatif digunakan oleh manajemen investasi/ manajemen portofolio, perusahaan dan lembagakeuangan serta investor perora ngan untuk mengelola posisi yang mereka miliki terhadap risiko dari pergerakan harga saham dan komoditas, suku bunga, nilai tukar valuta asing "tanpa" memengaruhi posisi fisik produk yang menjadi acuannya (underlying). Lihat https://id.wikipedia.org, diunduh tanggal 3 Oktober 2016.

${ }^{20} \mathrm{http}: / /$ rinaelina.blogspot.co.id, https://id.wikipedia.org.

${ }^{21}$ Forward contract adalah suatu persetujuan antara dua belah pihak untuk menjual atau membeli suatu aset (atau bentuk apapun juga) di suatu waktu yang telah ditetapkan sebelumnya. Oleh karena itu, tanggal penjualan dan tanggal penyerahan barang dilakukan berbeda. Kontrak serah ini digunakan untuk mengendalikan dan meminimalkan risiko, sebagai contoh risiko perubahan nilai mata uang (contoh: kontrak forward untuk transaksi mata uang) atau transaksikomoditi (contoh: kontrak serah untuk minyak bumi). Satu pihak setuju untuk membeli, pihak lain menjual, untuk suatu harga yang telah disetujui sebelumnya. Saat terjadi transaksiforward, belum terjadi pertukaran/pembayaranuang. Pembayaran dan pengiriman barang dilakukan sesuai dengan jadwal dan aturan yang telah disepakati. Harga forward berbeda dengan harga spot atau harga pada saat asset tersebut berpindah tangan (pada waktu tersebut (spot), biasanya dua hari kerja). https://id.wikipedia.org.

22 Futures contract atau kontrak berjangka dalam dunia keuangan merupakan suatu kontrak standard yang diperdagangkan pada bursa berjangka, untuk membeli ataupun menjual aset acuan dari instrumen keuangan pada suatu tanggal dimasa akan datang, dengan harga tertentu. Tanggal dimasa akan datang tersebut disebut dengan istilah tanggal penyerahan atau dikenal juga dengan istilah delivery date atau tanggal penyelesaian akhir (final settlement date). Harga tertentu disebut dengan istilah harga kontrak berjangka (futures price). Harga dari aset acuan pada saat tanggal penyerahan disebut dengan istilah harga penyelesaian (settlement price), lihat https://id.wikipedia.org.
} 
Mohammed Obaidullah, selain memperbolehkan trading forex secara spot, ia juga memperbolehkan transaksi forward untuk tujuan lindung nilai (hedging the value of money) dengan menggunakan konsep bai'salam. Transaksi Forward adalah transaksi pembelian dan penjualan valas yang nilainya ditetapkan pada saat sekarang dan diberlakukan untuk waktu yang akan datang, antara 2 x 24 jam sampai dengan satu tahun. Dia berpendapat bahwa transaksi forex exchange dalam bentuk uang viat atau uang kertas dapat diperdagangkan secara derivative karena tidak termasuk kategori mata uang emas dan perak yang hanya boleh ditransaksikan secara on the spot berdasarkan ketentuan bai' al-sarf. ${ }^{25}$

Untuk transaksi futures, Salehabadi dan Muhammad Aram sebagaimana dikutip oleh Nuradli Ridzwan Shah Mohd Dali dan Sanep Ahmad ${ }^{26}$, mencoba menawarkan format baru yang Islamicilly dengan mengkaitkan transaksi futures dengan akad Sulh (Compromise) dan Ji'alah (promised gift). Namun sayangnya mereka tidak menjelaskan secara terperinci tentang tehnik konversi transaksi future ke akad Sulh dan Ji'alah.

23 Option adalah kontrak di mana salah satu pihak menyetujui untuk membayar sejumlah imbalan kepada pihak yang lainnya untuk suatu "hak" (tetapi bukan kewajiban) untuk membeli sesuatu atau menjual sesuatu kepada pihak yang lainnya; misalnya saja ada seseorang yang khawatir bahwa harga dari stok XXX akan turun sebelum ia sempat menjualnya, maka ia membayar imbalan kepada seseorang lainnya (ini disebut "penjual" opsi jual /put option) yang menyetujui untuk membeli stok daripadanya dengan harga yang ditentukan di depan (strike price). Pembeli menggunakan opsi ini untuk mengelola risiko turunnya nilai jual dari stok XXX yang dimilikinya, dilain sisi si pembeli opsi mungkin saja menggunakan transaksi opsi tersebut untuk memperoleh imbalan jasa dan mungkin telah memiliki suatu gambaran bahwa nilai jual XXX tersebut tidak akan turun, lihat: https://id.wikipedia.org.

${ }_{24}$ Perjanjian swap adalah transaksi pertukaran dua valuta melalui pembelian atau penjualan tunai (spot) dengan penjualan/pembelian kembali secara berjangka yang dilakukan secara simultan dengan bank yang sama dan pada tingkat premi atau diskon dan kurs yang dibuat dan disepakati pada tanggal transaksi dilakukan. https://id.wikipedia.org/wiki/Tukar_menukar.

${ }^{25}$ Mohammed Obaidullah, "Financial Contracting in Financial Market. An Islamic Evaluation. "International Journal of Islamic Financial Services, Vol.3, No.3, Oct- Dec, 2001, pp. 2-12. Lihat http://islamicfinance.net.

${ }^{26}$ Nuradli Ridzwan Shah Mohd Dali dan Sanep Ahmad, “ A Review of Forward, Futures, and Options From The Shariah Perspective: From Complexity to Simplicity," makalah dipresentasikan di Seminar Ekonomi \& Kewangan Islam (SEKI 2005) Conference, ESSET Bangi, August 29-30, 2005, pp.13-14. Diakses dari http://www.kantakji.com. 
Wacana ini stidaknya menjadi alternative baru bagi kaum muslim untuk melakukan trading forex khususnya transaksi future yang sesuai dengan Islamic point view.

Ellen May, penulis buku Best Seller "Smart Trader Not Gambler" mengatakan bahwa trading merupakan Perfect Bussiness yang memberikan kebebasan waktu, tenaga, dan latar belakang. Potensi perolehan profit yang besar dalam waktu relative singkat serta tenaga yang minim membuat trading menjadi sebuah bisnis yang menarik. Resiko besar sebanding lurus dengan profit yang tinggi sehingga seorang trader sejati akan semakin tertantang dan pantang menyerah dalam menjalankan bisnis ini. Namun sebagaimana halnya sebuah bisnis, trading juga memerlukan pendalaman dan pembelajaran yang terus menerus oleh para traders. Berbagai analisa, baik itu analisa fundamental ataupun teknikal dengan berbagai indikatornya, serta money management yang baik, merupakan hal yang mutlak dikuasai oleh traders. Besarnya kerugian finansial yang dialami terutama oleh trader pemula, disebabkan oleh dua faktor utama, yaitu:

Pertama, Minimnya pengetahuan tentang dunia trading, seperti tidak memahami level yang tepat untuk open position, close position dan waktu yang tepat untuk take profit, apalagi untuk membatasi kerugian atau cut loss. Kondisi ini menempatkan trader seperti seorang penjudi yang mempertaruhkan hartanya dan berspekulasi untuk meraup keuntungan yang tidak pasti. Hal ini diperburuk dengan pola pikir yang salah tentang trading, di mana meraka menyamakan trading dengan arena judi yang harus dimenangkan. Trader type ini akan terjebak dalam siklus emosional berulang, yang menyebabkanmengambil keputusan berdasarkan emosi dan bukan berdasarkan analisa.

Kedua, Pysicologis trader yang tidak terkontrol dengan baik, sehingga kerugian finansial dapat terjadi meskipun mereka sudah menguasai banyak system dan strategi trading. Dominasi nafsu serakah/greed untuk memperoleh keuntungan sebesarbesarnya dalam waktu sigkat, membuat mereka tidak bisa konsisten dengan plan yang telah mereka buat sebelumnya. 
Pada dasarnya, trading online dapat menjadi bisnis yang menguntungkan jika disertai dengan manajemen, strategi serta system yang baik, sehingga kerugian finansial dapat diminimalisir. Ellen memperkenalkan konsep baru yang dinamakan dengan Mind MAPS, yang harus dikuasai dan dimiliki oleh seorang trader sebelum terjun ke bisnis trading online. Mind MAPS yang merupakan singkatan dari: Mindset, Management, Analisis, Psikologi Trading dan Strategi.

Para trader professional dunia, seperti Alexander Elder, Van K Thard, David Novac, Chuck Mellon, Martin J Pring, Jesse Livermore, Conrad Alvin Lim, dan lain-lain, memiliki kelima unsur yang terdapat dalam Konsep Mind MAPS. Dengan menguasai konsep tersebut, maka bisnis online trading baik itu trading forex, saham, commodities dan lain lain akan terhindar dari unsur gambling dan spekulasi, bahkan sebaliknya trading online akan menjadi sebuah bisnis yang dapat memberikan profit yang konsisten bagi trader. ${ }^{27}$

Pendapat senada juga dilontarkan oleh William O’ $\mathrm{Neil}^{28}$ bahwa untuk sukses di bisnis trading online, selain penguasaan strategi, kemampuan analisa juga merupakan faktor penting yang tidak boleh diabaikan, karena pada dasarnya Historical Price Pattern akan selalu cocok digunakan kapan saja dan di mana saja. Hal ini disebabkan oleh human nature yang tidak pernah berubah meskipun zaman berubah. Belajar pada kesuksesan orang terdahulu dan strategi yang mereka gunakan akan sangat membantu mewujudkan masa depan trader yang lebih baik. Berikut komentarnya: "Historical price patterns continue to work because human nature doesnot change, and neither does the law of supply and demand. Study past succesfull stock if you want to see what furute ones like you."

${ }^{27}$ Ellen May, Smart Trader not Gamblers (Jakarta: PT.Gramedia Pustaka Utama, 2016), 6 -16.

${ }^{28}$ William J. O'Neil adalah seorang Interprener, stockbroker dan writer asal Amerika yang lahir pada 25 Maret 1993. Dia juga pendiri Stock Brokearage Firm dan penggagas koran bisnis Investor's Business Daily. Bukunya yang populer antara lain How to Make Money in Stocks, 24 Essential Lessons for Investment Success and The Successful Investor. .https://en.wikipedia.org, Diakses pada tanggal 7 Oktober 2019 
Dalam kata pengantarnya untuk buku Ellen May, Prof. Roy Sembel Ph.D penulis buku The Art of Best Win (Becoming Smarter, Tougher, and Wiser Investors dan juga Direktur Bursa Berjangka (Jakarta Futures Exchange), menyimpulkan bahwa sebenarnya kerugian dalam trading dan pengalaman pahit yang dialami traderlah yang membentuk opini negatif di kalangan masyarakat tentang bisnis ini. Opini yang terkesan terburu-buru ini mennempatkan bisnis trading instrument keuangan dan komoditi menjadi semacam "momok" dan mengkambinghitamkan trading sebagai penyebab dari kerugian finansial yang menimpa banyak trader. Padahal sebenarnya kalau dirunut, kesalahan tidak terletak pada bisnisnya tapi terlepas dua factor penebab berikut ini:

1. Faktor Non Transaksi

Faktor pertama adalah korban penipuan yang diketahui berdasarkan pengaduan nasabah/trader yang tertipu pada perdagangan berjangka komoditi, dengan berbagai modus operandi, seperti:

a) Pembukaan Account di perusahaan pialang illegal.

b) Dokumen transaksi ditandatangani oleh wakil pialang tidak remis non sertifikasi dari BAPPETI.

c) Dana yang ditransfer nasabah pada saat pembukaan account bukan ke rekening khusus nasabah.

d) Transaksi tidak tercatat di mesin transaksi bursa (JAFeTS 3, Jakarta Futures Electronic Trading System generasi ketiga)

Teliti sebelum berinvestasi merupakan cara bijak untuk menghindari kehilangan uang akibat factor non transaksi.

2. Faktor Transaksi

Kerugian yang diakibatkan oleh faktor transaksi ini agak sulit dihindari terutama oleh trader pemula. Mereka bisa kehilangan uangnya hanya dalam sekejap. Untuk menghindari dan meminimalisir peluang kehilangan dana akbat faktor ini hendaknya trading dilakukan secara benar dan smart. Bahkan sebaliknya, trading instrumen keuangan termasuk forex akan menjadi lahan bisnis yang dapat memberikan keuntungan financial bagi banyak orang terutama para trader. ${ }^{29}$

${ }^{29}$ Ellen May, Smart Trader not Gamblers (Jakarta: PT.Gramedia Pustaka Utama, 2016), xiii. 
|Rafiqah

\section{Penutup}

Berdasarkan diskusi dan pemaparan di atas, disimpulkan bahwa meskipun sebagian besar ulama mempebolehkan trading forex online namun dengan kriteria dan syarat yang ketat, antara lain tidak dimaksudkan untuk spekulasi, tidak adanya Rollever Interest, tidak boleh ada fee bagi broker yang melakukan open positon lebih dari semalam, dan tidak boleh mengenakan kadar spread yang lebih tinggi menggantikan rollever interest.

Bila syarat dan ketentuan tersebut tidak terpenuhi maka trading forex secara online hukumnya adalah haram. Hal ini juga didukung oleh fatwa Majelis Ulama Indonesia (MUI). 


\section{Daftar Pustaka}

'Ațiyah, 'Adlan 'Atiyah Ramadan, Mausu'ah al-Qawa'id al Fiqhiyyah, (Iskandariah: Dar al-Qimmah-Dar al-Iman, tt.

Abdul Rahman, Aisyah, Raudha MD Ramli, Islamic Cross Currency Swap (ICCS): Hedging Against Currency Fluctuations: Emerald Emerging Markets Case Studies, Kuala Lumpur: Emerald Group Publishing Limited, 2015.

Abdul Rahman, Yahia, The Art of RF (Riba-Free) Islamic Banking and Finance: Tools and Techniques for Community-Based Banking, New Jersey: John Wiley \& Sons, 2014.

Abdulkader, Thomas, Interest in Islamic Economics, Canada: Routledge, 2008.

Abu Dawud, Sunan Abi Dawud, Beirut: Al-Maktabah al'Asriyyah, t.t.

Ackert, L. F. \& Deaves, R. Behavioral Finance: Psycology, Decision Making and Markets, South Western., 2010.

Ahmad Dal'ur, Muhammad, Raddu Muftarayat al-Riba, Haula Hukmi al-Riba wa Fawaid al-Bunuk, cet. ke-1, Lebanon: Dar al-Nahdhah al-Islamiyyah, 2002.

Al-Sawi, Muhammad Salah Muhammad, Musykilatu al-Istithmar fi al-Bunuk al-Islamiyyah wa Kaifa 'Alajaha al-Islam, Cairo: Dar Mujtama' dan Dar al-Wafa', 1990.

Al-Sayyid al-'Awdi, Rif'at dan 'Ali Jum'ah Muhammad, Mausu'ah al-Iqtisad al-Islamifi al-Masarif wa alNuqud wa al-Aswaq al-Maliyah, Cairo: Maktabah Dar al-Salam, 2009.

Al-Syarbini, Mugni al-Muhtaj, Dar al-Kutub al-'Ilmiyyah, 1415 $\mathrm{H}$.

Al-Tirmidhi, Al-Sunan, Cairo: Maktabah Mustaf'al Babi alHalabi, 1975.

Al-Zarqa', Mustafa Ahmad, Syarh al-Qawa'id al-Fiqhiyyah, Lebanon: Dar al-Ghuraba' al-Islami, 1983.

Al-Zuhaili, Wahbah, al-Mu'amat al-Maliyah al-Mu'asirah, Damaskus: Dar al-Fikr, 2002.

Al-Zuhaili, Wahbah, Fiqhu Islami wa Adillatuh, Jilid 4, Damaskus: Dar al-fikr, 2004.

Bin Nuh, Abdullah dan Oemar Bakry, Kamus Indonesia-Arab, Arab-Indonesia, Jakarta: PT. Bentara Antar Asia, 1991.

Cox, J.C., Rubinstein. M, Option Markets, Prentice-Hall, 1985. 
|Rafiqah

Chowdhury, Masudul Alam, Money in Islam: A Study in Islamic Political Economy, London, Routledge, 1997. , A Monetary System With 100-Per Cent Reserve Requirement and The Gold Standard: Theory, Fact And Policy,

Douglas, A, P Pontikis dan L Lovrencic, FX Trading: A Guide to Trading Foreign Exchange, Melbourne:Wrightbook 2012.

Elder, Alexander, Trading for a Living; Psychology, Trading Tactics Money Management, John Wiley and Sons, Inc, 1993.

El-Diwani, Tarek, The Problem With Interest (Sistem Bunga dan Permasalahannya), t.tp: Akbar Media Eka Sarana, 2005.

El-Gamal, Mahmoud A, Islamic Hedge Fund, Strategies \& Tools. Dubai: IIF, 2003.

El-Gammal Muhammad Sayyid, Abd. Monem, Islamic Economy, Beirut: Dar al-Kitab al-Lubnani, 1986.

Fatwa DSN No.40/DSN-MUI/X/203/2003 tentang Pasar Modal dan Pedoman Umum Penerapan Prinsip Syariah di Pasar Modal.

Haneef, Rafe, Ali Saeedi, dkk, Serries of Essay on Islamic Capital Market, SEO, Securities and Exchange Organization, Teheran, 2009.

Haroen, Nasrun, Fiqh Muamalah, Jakarta: Penerbit Gaya Media Pratama, 2000.

Hong, Ding Lai, The Foreign Exange Market, Kuala Lumpur: Institut Bank-Bank Malaysia, 2007.

Hull.JC, Options, Futures and Other Derivatives, $6^{\text {th }}$ Edition, Prentice Hall College Div, 2005.

Ismath Bacha, Obiyatulla, Financial Derivatives; Markets and Applications In Malaysia, Kuala Lumpur: Universiti Putra Publishers, 2001.

Kamali, Mohammad Hashim, Islamic Commercial Law, An Analysis of Futures and Options, Kuala Lumpur: Ilmiah Publishers, 2002.

Kettel, Brian, Islamic Finance in A Nutshell, United Kingdom: John Willey \& Sons Ltd., 2010.

Lim, Conrad Elvin, Secret Psychology of Millionaire Traders, ALKC, Singapore, 2008.

Manzoor, Nayyer, Islamic Economics A Welfare Approach, New Delhi: Adam Publisher \& Distributors, 1999. 
May, Ellen, Smart Traders not Gamblers, PT.Gramedia Pustaka Utama, Jakarta, 2016.

Mohd Dali, Nuradli Ridzwan Shah, dan Sanep Ahmad, A Review of Forward, Futures, and Options From The Shariah Perspective; From Complexity to Simplicity, Journal of ISEFED, Kuala Lumpur, 2006.

Muhammad Yusuf Kamal, Mustalahat al-Fiqhi al-Mali alMu'asir-Mu'amalat al-Suq, Cairo: Al-Ma'had al-'Alami li al-Fikri al-Islami, $1418 \mathrm{H}-1997 \mathrm{M}$.

Muslim, Sahih Muslim, Beirut: Dar Ihya' al-Turath al-'Arabi, t.t.

Nofrianto, Implementasi Syariah Complaint pada Saham Syariah Bursa Efek, Jambi: Suthan Taha Press, 2012.

Oxford Dictionary of Finance and Banking, Oxford University Press, 3nd ed, 2005.

Person, John, A Complete Guide to Technical Trading Tactics:How to Profit Using Pivot Points, Candlestick, and Other Indicators, John Willay and Sons, Inc, Hoboken, New Jersey, 2004.

Person, John, A Complete Guide to Technical Trading Tactics:How to Profit Using Pivot Points, Candlestick, and Other Indicators, John Willay and Sons, Inc, Hoboken, New Jersey, 2004.

Qahfi, Munzir, Asssiyat al-Tamwil fi al-Islami, Kuala Lumpur: ISRA, International Shari'ah Research for Islamic Finance, 2011.

Qal'aji, Muḥammad Rawwas, Mabahith fi al-Iqisad al-Islami: Min Usulih al-Fiqhiyyah, Beirut: Dar al-Nafais, 2000.

Rahman, Afzalur, Economic Doctrines of Islam, Lahore: Islamic Publication, 1990.

Rusli, Saiful Azhar, Critical Issues on Islamic Banking and Financial Market, Kuala Lumpur: Dinamas Publishing, 2005.

Tell Vibbi, Santo, When to Buy and Sell, Candlestick can, Vibbi Printing, 2007.

Tharp, Van K, Discliplined Trading: How to Trade Your Way to Financial Freedom, t.t.

Trading Forex: What Investors Want to Know, Chicago: National Future Association, 2010.

Vogel, Frank E dan Hayes, Islamic Law and Finance: Religion, Risk and Return, t.tp, Kluwer Law International, 1998.

Widjoatmojo, Sawiji, Cara Sehat Investasi di Pasar Modal, Jakarta: Gramedia, 2006. 
|Rafiqah

Yusuf Kamal Muhammad, Fiqh Iqtisad al-Suq: al-Nisyat alKhas, cet. Ke-3, Cairo: Dar al-Nasyr li al-Jami'at, 1998.

Ahmad, AA, SE yacob, dan MNM Zain, The Use of Wa'dan in Islamic Contract FX Forward: Weighting between Maslahah and Mafsadah, Journal of Asian Social Science, Vol.10, Issue 22, 2014.

Ahmad, Azlin Alisa, Halim, Mustafa 'Afifi Ab, The Concept of Hedging in Islamic Financial Transactions, Journal of Asian Social Science of Canadian Center of Science and Education 42, Vol.10, Issue 8, 2014.

Al-Darīr, Șiddīq Muḥammad al-Amịn, Al-Gharar in Contract and its Effect on Contemporary Transaction, IRT IsDB.Eminent Scholars Lectures Series No.9, 1997.

Al-Harran, Saad, Introduction: Cases in Islamic Finance, Journal of Arab Law Quarterly, Brill, Vol.15, No.3, 1999.

Alisa, Azlin, Ahmad, Halim dan Mustafa 'Afifi, The Concept of Hedging in Islamic Financial, Transactions, Asian Social Science Journal, Vol.10, Iss. 8, pp. 42-49, 2014.

Al-Saati, Abdul Raheem, The Permisible Gharar, Risk in Clasical Jurisprudence, Journal of Islamic Economic of King Abdul Aziz University, 2005.

Binti Abdull Manaf, Azwina Wati dan Ruzian Binti Markom, Currency Trading in Modern Islamic Bank in Malaysia, Malaysia: National University of Malaysia, 2015.

Capra, Umar, Islam and the Ecinomic Challenge, Leicester, UK: The Islamic Fondation, 1992.

Cavallo, A Eduardo, Output Volatility and Opennes to Trade: A Reasessement, Journal of The Latin America and Carribean Ecocomic Assosiation, Vol.1, No.1, 2008.

Dasuki, Asyraf Wajdi, Fiqh Issues in Short Selling as Implemented in the Islamic Capital Market in Malaysia, Vol.2.No.2, 2008.

DeBondt, W. dan R.Thaler, Does the Stock Market Overreact?, Journal of Finance, Vol.40, No.3.

El-Gamal, Mahmoud A, Al-Gharar, Risk and Insurance/Discussion Forum. International, Journal of Islamic Financial Services. Vol. 1, No. 1, 1998.

Fakhri Omar, Rafik dan Elleri Jones, Critical evaluation of the compliance of online Islamic FOREX trading with Islamic principles", International Journal of Islamic and Middle Eastern Finance and Management, Vol.8 Iss:1, 2015. 
Fakhry Rafik, Omar dan Eleri Jones, Critical evaluation of the compliance of online Islamic FOREX trading with Islamic principles, International Journal of Islamic and Middle Eastern Finance and Management, Vol. 8 Iss: 1, 2015.

Goodhart, Charles, Ryan Love, Richard Payne dan Dagfinn Rime, Analysis of Spread in the Dollar/Euro and Deutschemark/Dollar Foreign Exange Markets, Journal of Economic Policy, Villey, Vol.17, No.35, 2002.

Hamid, A, Transaksi Valas (Forex Exchange) Secara Online: Study Analitis Menurut Perspektif Islam, Jurnal EBIS (Ekonomi dan Bisnis Islam) IAIN Langsa, Vol. 1 No. 1, April 2016.

Ismath Bacha, Obiyatulla, Risk Management And Islamic Capital Markets, Islamic Capital Markets Conference, Securities Commission, March 2002, Kuala Lumpur, Malaysia.

Kamali, MH, Islamic Commericial Law: An Analysis of Futures, The American Journal of Islamic Social Sciences, 14 (2), 1996.

Karbalaee, H, Risk and Return in Retail Forex, Social Science Research Network, 15 Juni 2012.

Mohd Dali, Nuradli Ridzwan Shah dan Sanep Ahmad, "A Review of Forward, Futures, and Options From The Shariah Perspective: From Complexity to Simplicity," makalah dipresentasikan di Seminar Ekonomi \& Kewangan Islam (SEKI 2005) Conference, ESSET Bangi, August 29-30, 2005, Diakses dari http://www.kantakji.com.

Riyadi, Slamet, Financial Reeinginering Forward Transaction Into Islamic Forward to Incrase the Role of Islamic Banking in Indonesia in the Global Market, Interntional Journal of Advance Research, Vol. 3, Issue 12, 2015.

Rodoni, Ahmad, Daniel Sutadji dan Indo Yama Nasaruddin, Hipotesis Overreaction Market dan Size Firm di Bursa Efek Jakarta, Jurnal Etikonomi, Jurnal Ekonomi UIN Syarif Hidayatullah Jakarta, Vol.2, No.2, 2003.

Sami, Suwailem, Hedging in Islamic Finance, Jeddah: Islamic Devolepment Bank, Occasion Paper No.10. 